International Journal of Agriculture, Environment and Bioresearch

Vol. 5, No. 01; 2020

ISSN: $2456-8643$

\title{
FACTORS AFFECTING THE PERCEPTION OF FARMRERS ON IMPROVED SOYBEAN VARIETIES IN BAKO AREA, WEST SHEWA, ETHIOPIA
}

\author{
Abdulaziz Teha \\ Fedis Agricultural Research Centre, P.O. Box 904 ,Harar, Oromia Agricultural Research Institute, Ethiopia \\ https://doi.org/10.35410/IJAEB.2020.5467
}

\begin{abstract}
Soybean is one of the most important pulse crops categorized under oil crop. Ethiopia has an enormous potential for production of pulse crops in general and soybean in particular and it is also among the most important export crops. Despite the high production potential and the economic importance of the crop, soybean producers particularly small scale farmers did not economically benefited significant amount from its production. as such Low production and productivity, which is mainly associated with perception of farmers on improved technologies and poor marketing system. To this end, the objectives of this study were: to examine and document the experience of perception farmers on improved soybean varieties, analyse the determining factors that affect the perception of improved soybean production and assess the perception of farmers about improved soybean crop. Two stage sampling procedure were followed to select rural kebeles and households for the study. Four rural kebeles were selected purposively and 120 household heads were selected randomly using probability proportional to size sampling. Semi-Structured interview schedule were developed, pre-tested and used for collecting the essential quantitative data for the study from the sampled households. Focus group discussions on soybean production and marketing were used to generate qualitative data. The result of the study indicated that about $51.7 \%$ of the sample respondents were positive perception of the improved soybean varieties, while $48.3 \%$ negative perceptions. The focuses of the study were on the importance of demographic, social and institutional factors that affect the perception of improved soybean varieties in Bako areas. Therefore, policy and development interventions should give emphasis to improvement of such institutional support system so as to achieve wider perception increased productivity and income to small scale farmers.
\end{abstract}

Keywords: Perception, Soybean, Bako.

\section{INTRODUCTION}

Agriculture has been the foundation of Ethiopian economy and part of the history, culture, knowledge system and way of life for centuries. It contributes a great proportion to the gross national product (GNP) and, thus the improvement of agriculture stabilizes the economy, society and politics of the country. Almost $80 \%$ of the country's population are living in rural areas and are directly or indirectly linked to agriculture for their livelihood. According to recent data, agriculture accounts for $41 \%$ of the gross domestic product (GDP) and contributes to nearly $90 \%$ of Ethiopia's export earnings. Agricultural export economy is, however; subjected to the caprices 
of the weather; therefore, agricultural production is geared towards domestic consumption (CSA, 2012).As far as the main challenge of Ethiopia is food insecurity and malnutrition in the rural areas, mainly because of a low level of understanding of a balanced diet and lack of capacity to purchase animal source proteins to come out of the food insecurity problem and low export earnings from agricultural commodities. The country need to focus on increasing of agricultural production, high value commodities production for export and adoption of appropriate production technologies. There are several reasons to promote soybean production on small scale farmers' field, the Production and consumption of soybean improve the economic and nutritional status of the smallholder farmers and urban poor because soybean provides protein and fat .

Soybean is a multipurpose crop, which can be used for different kinds of foods, animal feed, soy milk, raw material for the processing industry, and it counter the effects like depletion of plant nutrients in the soil resulting from continuous mono-cropping of cereals increases soil fertility reduce malnutrition and decrease the risk of pest and diseases(Hailegiorgis, 2010). It is also the most nutritionally rich crop, as its dry seed contains the highest protein content among grain legumes (40 to $42 \%$ protein) with a good balance of the essential amino acids and has 18 $20 \%$ oil on a dry seed weight basis and also cheap and rich source of protein for farmers and urban poor, who have less access to animal source protein, because of their low purchasing capacity. Generally Soy-foods are considered to be nutritious and healthy based on their nutrient composition which includes protein, fat, carbohydrates, dietary fibers as well as minerals and phytoestrogenes (or isoflavones). (e.g. Asian diets rich in soybeans - with a lower risk of the socalled "western" diseases, i.e. coronary heart diseases, osteoporosis, hormone-dependent forms of cancer and menopausal symptoms) (Global database on children growth and malnutrition, 2003). Apart from its nutritive purposes, soybean oil is used industrially for paints, linoleum, printing inks, soaps, insecticides, and disinfectants. Soybean meal and soybean protein are used for synthetic fibre (artificial wool), adhesives, textiles, waterproofing, and firefighting foam ( Coulibaly.O, 2009). Although soybean breeding and production have been going on in Ethiopia since the 1950's, it was not easy to achieve wider dissemination and production of the crop. The main limitations were lack of know-how of the local farmers on the utilization aspect of the crop, unavailability of attractive market for the produce, and lack of systematic approach in popularizing the crop, which emphasized training farmers on the production of soybean, its utilization, and market potential (Mekonnen Hailu and Kaleb Kelemu, 2014).

The total hectare of land under soy bean production during the last 10 years has increased by 10 folds; while the total volume of production during the same period increased by 21 folds. Productivity level of soy bean is 1.06 ton/ha and this level is very low compared to its potential which could go up to 4 ton/ha if improved varieties are used(Mekonnen Hailu and Kaleb Kelemu, 2014).. The Ethiopia imports 15 million Kilograms of soy bean products and spend 11 million USD for importing various soy bean products every year. The average volume of soy bean export is 1.4 million Kilograms with trade deficit of 138 million Kilograms annually. The Value-to-Volume ratio for imported soy bean products has shown increasing trend during the last 12 years. Sudan, Indonesia, Djibouti, Netherlands and Vietnam are the highest volume recipient countries for Ethiopian soy bean export (Mekonnen Hailu and Kaleb Kelemu, 2014).

Agricultural research innovations have no value if they are not taken by the end users, identification of the determining factors adoption of improved soybean production technologies 
Vol. 5, No. 01; 2020

ISSN: $2456-8643$

with full recommendation package and improved soil conservation management practice help to enhance the productivity and offer better market opportunities, increase income level of the household, reduce malnutrition, improve soil fertility, reduce the risks of crop failure and the incidence of crop pests and diseases. As well as enable traditional farmers to increase productivity and increase their income. Hence this study is aimed at providing research, extension, and development institutions with valuable information that assists in improving the efficiency of communication and agricultural research, technology transfer by analysing the perception of farmers on soybean production technology and identify socioeconomic and institutional factors that influence the adoption of improved soybean varieties at Bako-Tibe district of West Shewa Zone.

\section{OBJECTIVES OF THE STUDY}

The general objective of the study is to investigate the perception of farmers and factors affecting the perception of farmers on improved soybean varieties in the study area.

The specific objectives of this study are:

1. To examine and document the perception of improved soybean varieties

2. To analyze the determining factors that affects the perception farmers on improved soybean varieties

\section{RESEARCH METHODOLOGY}

\subsection{Description of the Study Area}

The study was conducted in Bako-Tibe district of west shewa zone Oromia Regional State, it is located $250 \mathrm{~km}$ to west of the capital - Addis Ababa, in the central part of Ethiopia. The district is bordered with Gudeya Bila, Jima Rare and Jima Haro in the north; Bilo Boshe in the south; Eluglan (Ijaji) in the east; and Gobu Seyo in the west. The total population of the district is 133,584 of which 65,293 are men and 68291 are women with total household size of 22,880.

The district comprises 28 kebeles and each kebeles hosts one development center. Their mean annual temperatures is $20.4^{\circ} \mathrm{C}$ and mean annual rainfall of $1217 \mathrm{~mm}$, the main rainy season is from May to September and elevation ranging from 1500 to $2000 \mathrm{~m}$ above mean sea level. It is characterized by crop and livestock mixed farming system with moderate vegetation cover. Although there are crops like sorghum, tef(Eragrostis abyssinica), noug (Guizotia abyssinica), and pepper, Bako area is mainly known for maize production but soybean has recently been introduced to the area by Bako agricultural research center.

Based on the Ethiopian agricultural enumeration survey, in its area the maize cultivated area accounts for about $40 \%$ of the total cropped area (which was 22640 ha) and this $60 \%$ of the land under cereal crops (CSA, 2003). Farmers in the area produce maize for home consumption and for selling. Improved maize cultivars have been introduced in the district by Bako Agricultural Research Center (BARC).Primary schools are fairly distributed throughout the district in such a way that children from every household get access. In the district, there is one senior secondary school. Health services are limited to only accessible areas and the main town. There is one small general clinic set up by Mekane Eyesus and one governmental health center at the districts capital, Bako. Local markets are accessible to some PAs and there is one district market which serves as input and output market for the whole district. 


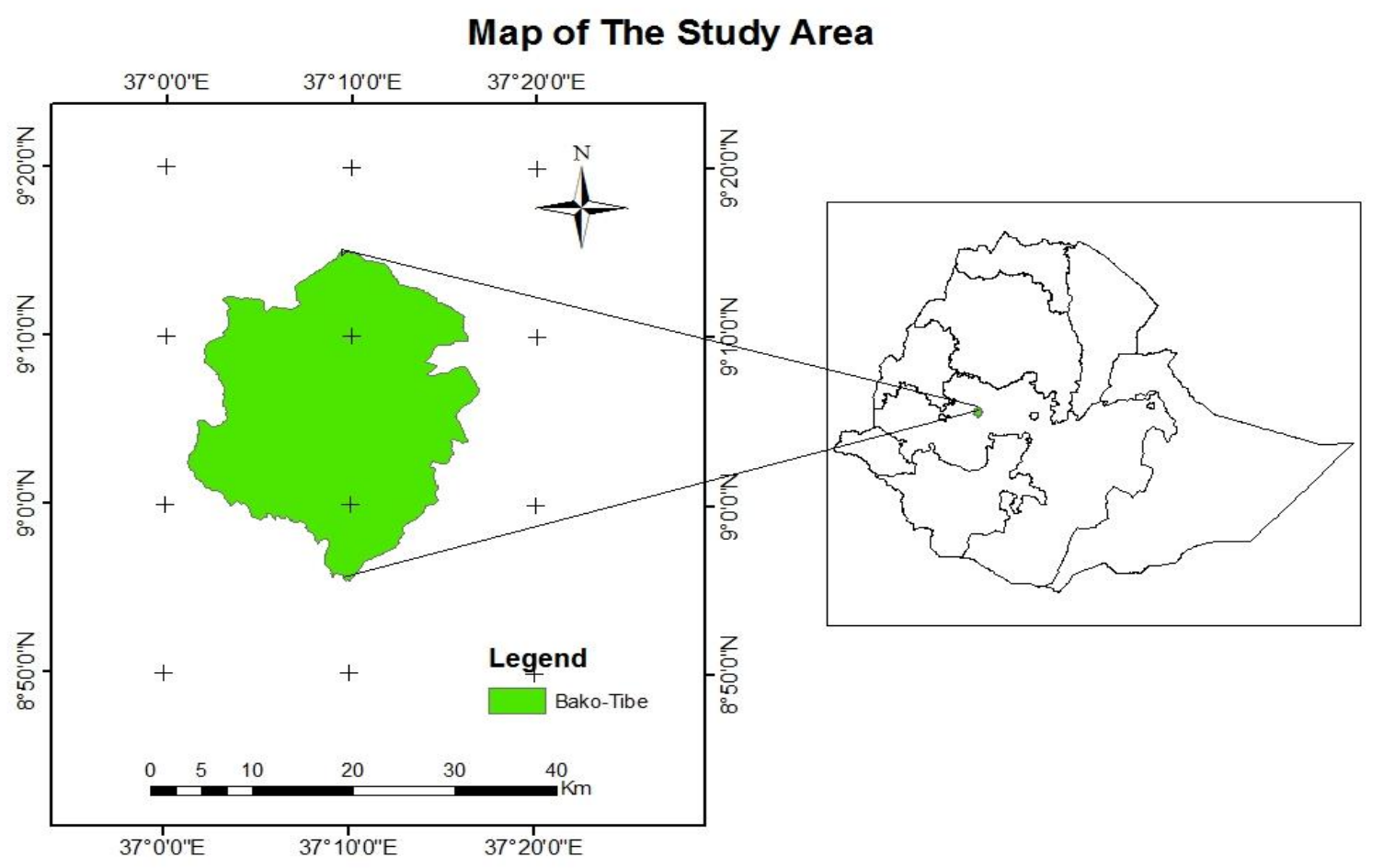

Figure 1. Map of the Study Area

Source: Bako Agricultural Research Center

\subsection{Study population and Sampling Procedure}

In this study, two stage sampling techniques were employed. The first stage is purposive selection of soybean growing Kebeles followed by selection of sample households. Four Kebeles were randomly selected out of eight kebeles covered by the Project in Bako-Tibe district Gambela Tare, Ongobo Bakanisa, Dambi Gobu and Dambi Dima were selected because of shortage of logistics to address all kebeles under the project.

Before selecting household heads to be included in the sample, soy bean grower household heads of each rural kebeles were identified in collaboration with kebele leaders and development agents of the respective rural kebeles. In the second stage, 120 farm household heads were selected from identified soy bean growers and non-growers using systematic random sampling technique taking into account probability proportional to size of soybean growers in each of four selected rural kebeles. As a result, the survey was administered and data were collected and analyzed on 120 respondents because of shortage of logistics. Accordingly, the number of respondents in each rural kebele was as shown in the Table1. 
International Journal of Agriculture, Environment and Bioresearch

Vol. 5, No. 01; 2020

ISSN: $2456-8643$

Table1. Number of respondents in each of the selected rural kebeles .

\begin{tabular}{llcccc}
\hline S.no & PA Name & $\begin{array}{c}\text { total No } \\
\text { HH }\end{array}$ & $\begin{array}{l}\text { Selected No. of } \\
\text { sampled HH }\end{array}$ & Growers & Non-growers \\
\hline & & & & & \\
1 & Dambi Dima & 294 & 25 & 14 & 17 \\
2 & Dambi Gobu & 329 & 27 & 17 & 18 \\
3 & Gambela Tare & 416 & 35 & 23 & 10 \\
4 & Ongobo Bakanisa & 397 & 33 & 62 & 58 \\
\hline
\end{tabular}

\subsection{Methods of Data collection}

The research mainly focused on both primary and secondary data related to soybean production were collected to achieve the objectives of this study. As the main focus of this study was on primary data, it was collected from the sample households using structured questionnaires that were designed to generate data on demographic, socio-economic, and institutional factors which influence the perception of soybean in the Bako districts.

Both primary and secondary data were collected in this study, Primary data on soybean varieties grown, production practices, associated farm and farmers characteristics, institutional and psychological( perceptions) related were collected. Secondary data for this study were collected from book, journals, published and unpublished documents from Zone and district agricultural offices and internet to supplement primary data.

Primary data were collected using quantitative approach by means of household survey using a set of pre-tested questionnaires. The qualitative method of data collection was also employed. Survey involves interview and direct observations. Semi-structured group discussion and individual interviews were held to have reactions of the farmers concerning their detail experiences and their perceptions of soybean varieties and their experience in soybean production knowledge. The interview was scheduled to pre-test before actual data collection and amendments was made to modify some of the questions to make them fit to the context. The enumerators conducted the interview with close supervision of the researcher in the local language.

\subsection{Method of Data Analysis}

The coding of data collected for the analysis was done after collection and before feeding the data in to the computer. The data were analysed using software SPSS version 20.0 and stata version 11.0. Appropriate techniques and procedures like cross tabulation were used in the analysis to identify the influence of personal and institutional factors on farmers' perception of improved soybean varieties. Descriptive statistics such as mean, standard deviation (SD), frequencies, and percentages were used to have a clear picture of the characteristics of sample units.

\section{RESULTS AND DISCUSSION}


This part is mainly concerned with the description and interpretation on the findings the survey result. As already noted, a semi-structured interview schedule was administered to 120 sample households in the study area, Bako Tibe wereda. The main aim was investigating farmers' perception on soybean production varieties. The interview schedule was designed in such a way that it enables to collect data on socio-psychological and institutional characteristics as well as on the farmers' perception towards soybean production technology.

\subsection{Frequency of contact to the extension agents}

It was hypothesized that households who were more frequently visited by the development agents develop a capacity to receive and analyze information which leads to make decision to apply new technologies better than those with less frequently visited households. Access to relevant agricultural information enhance farmers' awareness and contributes for better understanding of new technologies which resulted in change of behavior that leads to make decision to adopt or reject new agricultural technology.

In this regard, from the total sampled households that had got extension service. Concerning adopters and non-adopters, about 51.7 percent and 48.3 percent were received extension service; respectively (Table 1).This indicated that adopters and non-adopters get almost equal extension services. In the adopters and non-adopters categories 24.2 percent and 15.8 percent respectively get extension services all time listed in the table blow, respectively which was found statistically significant $(\mathrm{t}=18.48)$. This implies that frequent extension contact has contributed for adopters and non-adopter group to have access of information, knowledge and observation about soybean production technology.

Table1. Frequency of farmers visited by development agent per year

\begin{tabular}{lrrrrrrrr}
\hline Frequency & \multicolumn{2}{c}{ Adopters } & \multicolumn{2}{c}{ Non-adopters } & \multicolumn{2}{c}{ Total } & & \\
of visit & $\mathrm{N}$ & \multicolumn{1}{c}{$\%$} & \multicolumn{1}{c}{$\mathrm{N}$} & \multicolumn{1}{c}{$\%$} & $\mathrm{~N}$ & \multicolumn{1}{c}{$\%$} & t-value & P-value \\
\hline Land preparation & \multicolumn{1}{c}{14} & 11.7 & 13 & 10.8 & 27 & 22.5 & & \\
During input provision & 11 & 9.1 & 7 & 5.8 & 18 & 15.0 & & \\
At sowing time & 8 & 6.7 & 17 & 14.2 & 25 & 20.8 & $18.482 * * *$ & 0.000 \\
During credit taking & 0 & 0.0 & 2 & 1.7 & 2 & 1.7 & & \\
All above listed time & \multicolumn{1}{c}{29} & 24.2 & \multicolumn{1}{c}{19} & 15.8 & 48 & 40.0 & & \\
\hline
\end{tabular}

Source: Own survey result/2016, statistically significant at less than $1 \%$ probability

\subsection{Attendance on the field day and training}

Attending extension events was measured by giving scores to respondent farmers' participation in the two extension events namely training and field visit, Training is a means to impart knowledge and develop skill of farmers to adapt new practices. It is a perquisite to avoid complexity of new technology at the time of implementation. Whenever new technology introduced to the farming community, training becomes an important ingredient to enhance the perception of new technology. Training is also an important aspect to improve farmers' performance. It equips farmers with new knowledge and skill, which help them to perform new practice properly. If a farmer has no skill and know-how about certain technology, he/she may have less probability of perception. The skill acquired through training helps to carry out a new technology effectively and efficiently. If farmers are well trained in new practice, they may not 
need outside support later. They can properly implement the recommendation. Undertaking field trial on one's farm is very important because it helps other farmers to observe the crop performance flowering, maturity, vegetative status, productivity and yield of new technology practically. This situation may facilitate the perception process. In other words attending demonstration is an important means, which create concrete awareness among the target group on the practice. It is also a means of passing information to initiate farmers to try and then perceive the better practice into their farm.

\section{Table 2. Farmers' participation in different extension events}

\begin{tabular}{lccccccccc}
\hline & \multicolumn{1}{c}{ Adopters } & \multicolumn{2}{c}{ Non-adopters } & \multicolumn{2}{c}{ Total } \\
Attendance & Response & $\mathrm{N}$ & $\%$ & $\mathrm{~N}$ & $\%$ & $\mathrm{~N}$ & $\%$ & $\chi 2$-value & P-value \\
\hline Contact with the & yes & 50 & 41.7 & 25 & 20.8 & 75 & 62.5 & & \\
extension agent & No & 12 & 10.0 & 33 & 27.5 & 45 & 37.5 & $18.020 * * *$ & 0.000 \\
Participation & yes & 54 & 45.0 & 27 & 22.5 & 81 & 67.5 & & \\
in the field days & No & 8 & 6.7 & 31 & 25.8 & 39 & 32.5 & $22.455 * * *$ & 0.000 \\
Participation on & yes & 53 & 44.2 & 27 & 22.5 & 80 & 66.7 & & \\
the training & No & 9 & 7.5 & 31 & 25.8 & 40 & 33.3 & $20.439 * * *$ & 0.000 \\
\hline
\end{tabular}

Source own survey data 2016 significant at less than $1 \%$ probability

Table 2 indicates that out of the sampled household 41.7 percent of adopters of soybean production technology and 20.8 percent of have a contact with extension agents and also $10 \%$ of adopters and $27.5 \%$ of non-adopters don't have contact with extension agents, it was found statistically significant $(\chi 2=18.020)$ participation on field days $(\chi 2=22.455)$. Out of total 120 sampled farmers $45 \%$ of adopters and $22.5 \%$ non-adopters attended field days on improved soybean production technology and $6.7 \%$ of adopters and $25.8 \%$ non-adopters did not attend on field days. Concerning farmers' attendance on the training programs, out of total 120 farmers interviewed $44.2 \%$ of adopters and $22.5 \%$ of non-adopters were found to attend and the rest 7.5 $\%$ of adopters and $25.8 \%$ of non-adopters did not attend in the training program.

\subsection{Mass media exposure}

The perception process of agricultural technologies depends primarily on access to information and on the willingness and ability of farmers to use information channels available to them. The role of information in decision-making process is to reduce risks and uncertainties to enable farm households to make right decision on improved agricultural technologies. Mass media play the greatest role in provision of information in shortest possible time over large area of coverage. However, as compared to other communication channels radio the most widely used media in the rural area, its effect on behavioral change is weak as it is limited to awareness creation than skill development. But, as far as awareness is pre-requisite for behavioral change, still its role cannot be underestimated. Hence, mass media exposure was expected to positively influence the perception of improved soybean production package. The survey result on mass media exposure of sample respondents is provided in Table 3. 
International Journal of Agriculture, Environment and Bioresearch

Vol. 5, No. 01; 2020

ISSN: $2456-8643$

Table.3. Distribution of respondents with respect to radio listening habit

\begin{tabular}{|c|c|c|c|c|c|c|c|c|}
\hline \multirow[t]{3}{*}{ Use of radio } & \multicolumn{6}{|c|}{ Category of the respondents } & \multirow{3}{*}{\multicolumn{2}{|c|}{ 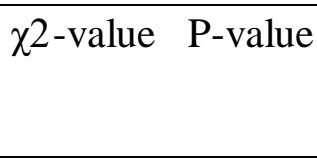 }} \\
\hline & \multicolumn{2}{|c|}{ Adopters } & \multicolumn{4}{|c|}{ Non-adopters Total } & & \\
\hline & $\mathrm{N}$ & $\%$ & $\mathrm{~N}$ & $\%$ & $\mathrm{~N}$ & $\%$ & & \\
\hline Never & 12 & 10.0 & 29 & 24.2 & 41 & 34.2 & & \\
\hline Rarely & 9 & 7.5 & 3 & 2.5 & 12 & 10.0 & & \\
\hline Occasionally & 29 & 24.1 & 18 & 15.0 & 47 & 39.2 & $13.979 * * *$ & 0.007 \\
\hline Often & 11 & 9.2 & 8 & 6.7 & 19 & 15.8 & & \\
\hline Very often & 1 & 0.8 & 0 & 0.0 & 1 & 0.8 & & \\
\hline
\end{tabular}

Source own survey 2016 significant at less than $1 \%$ probability

Concerning radio listening habit of respondents in the study area, $10 \%$ of adopters of soybean and $24.2 \%$ of non- adopters never listen to the radio programs whereas $7.5 \%, 24.1 \%, 9.2 \%$ and $0.8 \%$ of the adopters rarely, occasionally, often and very often listen to the radio respectively and also $2.5 \%, 15.0 \%, 6.7 \%$ and $0.0 \%$ of were rarely non- adopters, occasionally, often and very often listen to the radio respectively (Table 3).Surprisingly, majority of radio listeners in the study area do not pay attention to agricultural programs. The transmitted program is irrelevant to the farmers' own context. It could also be attributed to lack of favorable perception towards the program.

\subsection{Farmers' Perception towards soybean production Technology}

This section presents the result and discussion on farmers' perception as measured by the Likert Scale designed specifically to answer research question number one of this study 'what is farmers' perception towards soybean production technology?' Accordingly, different perception statements were presented to the sampled households. The interview schedule was designed to collect data on the farmers' perception towards soybean production technology as a factor of some institutional, socio-economic and physiological impact, complexity or difficulty of the technology and perceived advantage of the technology. Socio-economic factors such as expectation of profit and yield increment as a result of, ability to afford the required labor for soybean production activities, farmers'; biophysical expectation on the advantages of soybean natural soil fertility improvement. Hence, a total of 11 perception statements (six positive and five negative statements) were developed. Adopters of soybean technology were provided with all statements while only five statements were presented for non-adopters. The response for each question was coded with numbers $(-1=$ Disagree, $0=$ don't know/neutral, $1=$ Agree for positive statements and 1=Agree, $0=$ don't know/neutral, $-1=$ Disagree for negative statements). Finally, by summing up the mean value of each statement, the perception was coded with positive and negative values towards the perception object, i.e., soybean technology. Percentage, mean and standard deviation were also used to explain the perception of respondents towards each perception object. The correlation matrix, which was used to see the degree of association between each statement, is given in Table .4 . 
Vol. 5, No. 01; 2020

ISSN: $2456-8643$

Table.4.Inter-Item Correlation Matrix of farmers' perception toward soybean production Technology HGY EM GVS LCPR FUE

SFI LMD

LCD $\quad$ LST $\quad$ SED $\quad$ MLD

HGY 1.000

EM $-.045 \quad 1.000$

GVS .009 $\quad .215 \quad 1.000$

$\begin{array}{llll}\text { LCPR.008 } & .177 \quad .028 & 1.000\end{array}$

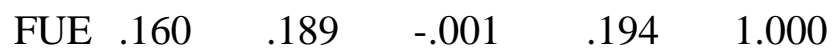

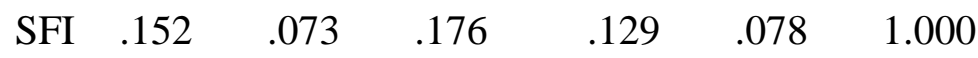

$\begin{array}{lllllll}\text { LMD }-.084 & -.174 & -.030 & .010 & .049 & -.010 & 1.000\end{array}$

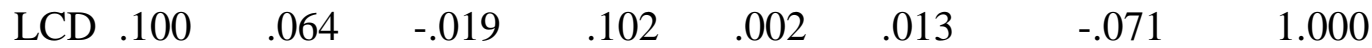

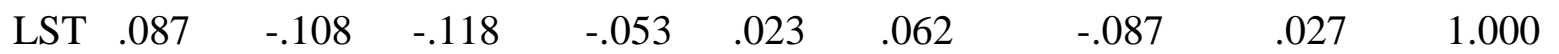

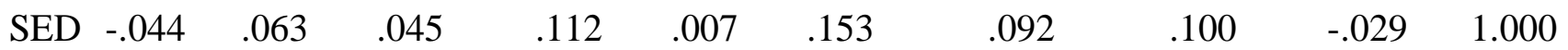

$\begin{array}{lllllllllll}\text { MLD .117 } & .040 & .016 & -.024 & -.067 & -.009 & -.041 & .062 & .090 & -.089 & 1.000\end{array}$

Source: Own survey data 2016

Accordingly, the result of correlation matrix shows consistency or agreement of values within cases. However, in some cases, the presence of some items influences negatively. Hence, reliability analysis was undertaken for all statements to see the degree of scale reliability of each perception statements and to determine potential items which influence respondents' perception towards soybean production technology. The alpha $(\alpha)$ level of all statements is 0.297 . All items with a value of greater than 0.297 were dropped as they are not reliable to estimate respondents' perception

Table.5.Reliability Analysis for perception statements toward soybean production Technology

\begin{tabular}{|llll|}
\hline & $\begin{array}{l}\text { Scale Mean if } \\
\text { Item Deleted }\end{array}$ & $\begin{array}{l}\text { Scale } \\
\text { Variance if } \\
\text { Item Deleted }\end{array}$ & $\begin{array}{l}\text { Cronbach's } \\
\text { Alpha if Item } \\
\text { Deleted }\end{array}$ \\
\hline HGY & 1.61 & 9.383 & .263 \\
EM & 1.63 & 9.276 & .256 \\
GVS & 1.70 & 9.539 & .284 \\
LCP & 1.96 & 8.965 & .234 \\
FUE & 1.77 & 9.071 & .244 \\
SFI & 1.79 & 8.788 & .214 \\
LMD & 1.36 & 10.635 & .341 \\
LLCD & 1.68 & 9.314 & .273 \\
LST & 2.16 & 10.000 & .336 \\
SED & 2.21 & 9.242 & .273 \\
MLD & 2.39 & 9.871 & .309 \\
\hline
\end{tabular}

Source: Own survey data 2016

As shown in the above Table.5. Of the total eleven statements, three statements low market demand (LMD), low storability (LST) and much labor demanding (MLD) were found with alpha 
value of greater than 0.297 . Hence, these three statements were dropped and the remaining eight reliable statements were used to analyze respondents' perception towards soybean production technology.

\subsection{Interpretation of empirical results:}

As indicated earlier, adopters of soybean production technology were provided with all perception statements whereas only six statements were presented for non-adopters. Of all statements presented for adopters, eight were found reliable to analyze their perception towards soybean production technology. Similarly, out of six statements presented for non-adopters, only three statements were found to be reliable in analyzing non-adopters' perception towards soybean production technology. The distribution of adopters and non-adopters farmers' responses to statements are given below in Table 6 and Table 7, respectively.

Table.6.Adopter farmers' response to perception statements; Bako Tibe Wereda, West Shewa ,Ethiopa

\begin{tabular}{|c|c|c|c|c|c|c|}
\hline \multirow[t]{2}{*}{$\mathrm{SN}$} & \multirow[t]{2}{*}{ Perception statements } & \multirow[t]{2}{*}{ Influence } & \multicolumn{2}{|c|}{ Adopters (\%) } & \multicolumn{2}{|r|}{ Mean (SD) } \\
\hline & & & Agree & Neutral & Disagree & \\
\hline Q1 & SB has High grain yield & $+\mathrm{ve}$ & $57.9 \%$ & $22.6 \%$ & $17.7 \%$ & $0.42(0.78)$ \\
\hline Q2 & Early maturity of SB & $+\mathrm{ve}$ & $69.4 \%$ & $16.1 \%$ & $14.5 \%$ & $0.55(0.74)$ \\
\hline Q3 & SB has good vegetative status & $+\mathrm{ve}$ & $61.3 \%$ & $14.5 \%$ & $24.2 \%$ & $0.37(0.85)$ \\
\hline Q4 & Low cost of production of SB & $+\mathrm{ve}$ & $50.0 \%$ & $19.4 \%$ & $30.6 \%$ & $0.19(0.88)$ \\
\hline Q5 & High fertilizer use efficiency of SB & $+\mathrm{ve}$ & $51.6 \%$ & $22.6 \%$ & $25.8 \%$ & $0.26(0.85)$ \\
\hline Q6 & Better soil fertility improvement of S & $B+v e$ & $54.8 \%$ & $19.4 \%$ & $25.8 \%$ & $0.29(0.86)$ \\
\hline Q7 & Low consumption demand of SB & -ve & $64.5 \%$ & $9.7 \%$ & $25.8 \%$ & $0.39(0.88)$ \\
\hline Q8 & Shortage of SB seed & -ve & $41.9 \%$ & $12.9 \%$ & $45.2 \%$ & $-0.03(0.94)$ \\
\hline
\end{tabular}

The result of reliability analysis showed that respondents' perception towards soybean production technology is influenced by a set of perception items. With respect to the perceived advantage of the technology; Q2, Q3 and Q1 were found to be potential factors to explain adopter farmers' perception towards soybean technology. Of the total adopter respondents, $54.8 \%$ agreed on the contribution of soybean production technology in soil fertility improvement.

Table.7.Non-adopter farmers' response to perception statements; Bako Tibe Wereda, West Shewa ,Ethiopa

\begin{tabular}{|c|c|c|c|c|c|c|}
\hline \multirow[t]{2}{*}{$\mathrm{SN}$} & \multirow[t]{2}{*}{ Perception statements } & \multirow[t]{2}{*}{ Influence } & \multicolumn{3}{|c|}{ Non-adopters (\%) } & \multirow[t]{2}{*}{ Mean (SD) } \\
\hline & & & Agree & Neutral & Disagree & \\
\hline Q1 I & onsumption demand of SB & -ve & $60.3 \%$ & $10.4 \%$ & $29.3 \%$ & $0.31(0.90)$ \\
\hline Q2 & age of SB seed & -ve & $25.9 \%$ & $13.8 \%$ & $60.3 \%$ & $-0.34(0.87)$ \\
\hline Q3 1 & r soil fertility improvement & f SB +ve & $44.8 \%$ & $27.6 \%$ & $27.6 \%$ & $0.17(0.84)$ \\
\hline
\end{tabular}

Similarly, $44.8 \%$ non-adopters showed their agreement concerning the contribution of soybean production technology in soil fertility improvement. With this specific item, the mean value of all responses for adopters and non-adopters i.e., 0.29 and 0.17 , respectively, indicates that both 
adopters and non-users have positive perception towards soybean production technology as a result of its advantage in conserving natural resources in general. Out of the total adopters of soybean production technology, 69.4\% expressed their agreement for Q2 i.e., "Early maturity status of soybean " and $61.3 \%$ of respondents expressed their agreement in favor of Q3 i.e., "soybean has good vegetative status ", respectively. The mean value for Q2 (0.55) and Q3 (0.37) indicates positive perception of adopter farmers towards soybean production technology as a result of perceived advantage of the technology in increasing benefit and yield.

Of the total respondents, majority of non-adopter $(60.3 \%)$ showed their agreement that soybean production technology is much low local consumption demand $(0.31)$ clearly shows their negative perception soybean production technology due to low local consumption demand and also, the adopters $64.5 \%$ of adopter respondents agreed that soybean production technology low local consumption demand. i.e., " Shortage of seed" was presented for both adopters and nonadopters soybean production technology. Of the total adopters' respondents, $41.9 \%$ of respondents showed their agreement on the statement while $58.1 \%$ are not in favor of the statement. Similarly $25.9 \%$ of non-adopters respondents agreed that soybean shortage of seed. The proportion of adopters who agreed on the statement (Q8) is relatively higher than nonadopters $(58.1 \%)$ of soybean production technology.

However, the mean value of both users $(-0.03)$ and non-users $(-0.34)$ showed their negative perception towards soybean production technology as a result of seed shortage which mainly focus on the difficulty associated with the technology were presented for adopter respondents.Q1 were reliable to analyze their perception towards soybean production technology. Out of the total sample adopter respondents, $57.9 \%$ agreed that soybean has high grain yield.

The mean value (0.42) adopter has positive perception towards soybean production technology. Q4 "Low cost production" and Q5 "high fertilizer use efficiency" of soybean production technology50.0\% of respondents agreed soybean production technology has low cost of production and 51.6\% soybean production technology has got high fertilizer use efficiency. The mean value for this statement Q4 (0.19) and Q5 (0.26) showed that a major opportunity which in turn contribute to develop positive perception towards the soybean production technology.

\section{CONCLUSION AND RECOMMENDATIONS}

\subsection{Conclusion}

In this regard, from the total sampled households that had got extension service. Concerning adopters and non-adopters, about 51.7 percent and 48.3 percent were received extension service; respectively (Table 1).This indicated that adopters and non-adopters get almost equal extension services. In the adopters and non-adopters categories 24.2 percent and 15.8 percent respectively get extension services all time listed in the table blow, respectively which was found statistically significant $(\mathrm{t}=18.48)$. This implies that frequent extension contact has contributed for adopters and non-adopter group to have access of information, knowledge and observation about soybean production technology.

The study result indicates that out of the sampled household 41.7 percent of adopters of soybean production technology and 20.8 percent of have a contact with extension agents and also $10 \%$ of adopters and $27.5 \%$ of non-adopters don't have contact with extension agents ,it was found statistically significant $(\chi 2=18.020)$ participation on field days $(\chi 2=22.455)$. 
Concerning radio listening habit of respondents in the study area, $10 \%$ of adopters of soybean and $24.2 \%$ of non- adopters never listen to the radio programs whereas $7.5 \%, 24.1 \%, 9.2 \%$ and $0.8 \%$ of the adopters rarely, occasionally, often and very often listen to the radio respectively and also $2.5 \%, 15.0 \%, 6.7 \%$ and $0.0 \%$ of were rarely non- adopters, occasionally, often and very often listen to the radio respectively (Table 3 ).Surprisingly, majority of radio listeners in the study area do not pay attention to agricultural programs. The transmitted program is irrelevant to the farmers' own context. It could also be attributed to lack of favorable perception towards the program.

\subsection{Recommendations}

Attending extension events was measured by giving scores to respondent farmers' participation in the two extension events namely training and field visit, Training is a means to impart knowledge and develop skill of farmers to adapt new practices. Whenever new technology introduced to the farming community, training becomes an important ingredient to enhance the perception of new technology. Training is also an important aspect to improve farmers' performance. They can properly implement the recommendation. Undertaking field trial on one's farm is very important because it helps other farmers to observe the crop performance flowering, maturity, vegetative status, productivity and yield of new technology practically. This situation may facilitate the perception process

The perception process of agricultural technologies also depends primarily on access to information and on the willingness and ability of farmers to use information channels available to them. Mass media play the greatest role in provision of information in shortest possible time over large area of coverage. However, as compared to other communication channels radio the most widely used media in the rural area, its effect on behavioral change is weak as it is limited to awareness creation than skill development. But, as far as awareness is pre-requisite for behavioral change, still its role cannot be underestimated. Hence, mass media exposure was expected to positively influence the perception of improved soybean production package.

\section{REFERENCES}

CSA (Central Statistical Agency of Federal Democratic Republic of Ethiopia), 2000-2012. Annual report

Coulibaly O.et.al., (2009) Situation and Outlookfor Cowpea and Soybean in Sub-Saharan Africa

Global database on children growthandmalnutrition.(2003):Available at[htt://who.int/nutgrwhdb] Retrieved March 13, 2007

Hailegiorgis, B. (2010): Export performance of oilseeds and its determinants in Ethiopia. Haramaya University, College of Agriculture and Environmental Science, Department of Agricultural Economics.

Mekonnen Hailu and Kaleb Kelemu .Trends in Soy Bean Trade in Ethiopia Research .Journal of Agriculture and Environmental Management. Vol. 3(9), pp. 477-484, September, 2014Available online at http://www.apexjournal.org ISSN 2315 - 8719@ 2014 Apex Journal International 